\title{
Ethylchlorformate Vaccine
}

National Cancer Institute

\section{Source}

National Cancer Institute. Ethylchlorformate Vaccine. NCI Thesaurus. Code C28579.

A tumor vaccine comprised of ethylchlorformate polymerized tumor protein, obtained by treating tumor cells with ethylchloroformate to produce a tumor-specific immunotherapeutic agent. $(\mathrm{NCl})$ 